\title{
KOMUNIKASI KONFLIK DALAM PENGELOLAAN SUMBERDAYA PERIKANAN DI KAWASAN TAMAN NASIONAL KARIMUNJAWA \\ (Kasus: Desa Karimunjawa, Kecamatan Karimunjawa)
}

\author{
(Conflict Communication of Fisheries Management in \\ Karimunjawa National Park)
}

\author{
Titania Aulia ${ }^{1}$, Sarwititi Sarwoprasodjo ${ }^{2}$, Arif Satria ${ }^{2}$ \\ ${ }^{1}$ Program Keahlian Komunikasi, Program Diploma IPB \\ ${ }^{2}$ Fakultas Ekologi Manusia IPB, Jl. Kamper Kampus IPB Dramaga \\ E-mail: titaniaaulia@gmail.com
}

\begin{abstract}
Differences of perception in the fisheries resources management in the area of Karimunjawa National Park (KNP) is still perceived by all stakeholders, especially the Karimunjawa National Park Officer (KNPO) as authorities. As $K N P O$, attempts to communicate with the fishermen, even with using of communication media, such as notice boards, poster, leaflet, and implementation of the No Take Zone Campaign Program. Fishermen believe that the lack of information due to lack of communication, so KNPO regarded as enemies of fishermen. The purpose of this study was to analyze the perception of fishermen on aspects of fisheries resources management, resulting in conflict due to differences in perception. This study has revealed that the social characteristics (age and experience of fisheries resources management) and trust of KNPO correlated to perception of fishermen in fisheries resources management aspects. The characteristics of fishermen who have different perceptions with KNPO were fishermen who lived near KNPO office, fishermen who did not participate in the activities of KNPO, young age, and fishing experience is still lacking.
\end{abstract}

Keywords: communication media, perception, conflict

\section{ABSTRAK}

Perbedaan persepsi dalam pengelolaan sumberdaya perikanan di kawasan Taman Nasional Karimunjawa (TNKJ) masih dirasakan oleh para pemangku kepentingan terutama pihak Balai Taman Nasional Karimunjawa (BTNKJ) sebagai pemegang otoritas. Pihak BTNKJ berupaya untuk berkomunikasi dengan nelayan, bahkan dengan menggunakan media komunikasi, seperti papan pengumuman, poster, leaflet, dan pelaksanaan Program Kampanye Zona Inti. Nelayan beranggapan bahwa masih kurang mendapatkan informasi karena kurangnya komunikasi, sehingga BTNKJ dianggap sebagai musuh nelayan. Tujuan dari penelitian ini adalah untuk menganalisis persepsi nelayan terhadap aspek pengelolaan sumberdaya perikanan, sehingga menyebabkan konflik akibat perbedaan persepsi. Penelitian ini telah mengungkapkan bahwa karakteristik sosial (umur dan pengalaman pengelolaan sumberdaya perikanan) dan bentuk kepercayaan terhadap pihak BTNKJ berhubungan dengan persepsi nelayan terhadap aspek pengelolaan sumberdaya perikanan. Ciri-ciri nelayan yang memiliki perbedaan persepsi dengan BTNKJ adalah nelayan yang tempat tinggalnya berdekatan dengan kantor BTNKJ, nelayan yang tidak diikutsertakan dalam kegiatan BTNKJ, umur yang masih muda, dan pengalaman melaut yang masih kurang.

Kata kunci: media komunikasi, persepsi, konflik 


\section{PENDAHULUAN}

Kawasan konservasi perairan Indonesia memiliki luas 15.764.210,85 ha (Direktorat Konservasi Kawasan dan Jenis Ikan 2013), sehingga diperlukan adanya upaya pengelolaan kawasan. Salah satu bentuknya berupa taman nasional laut yang dikelola oleh Balai Taman Nasional Karimunjawa (BTNKJ) di bawah pengawasan langsung dari Kementerian Kehutanan yang memiliki luas sebesar 111.625,0 ha. Pengelolaan TNKJ berupa sistem zonasi yang penetapannya dilakukan oleh pemerintah pusat melalui SK Dirjen PHKA No. 127/Kpts/DJVI/1989. Sejak penetapan taman nasional tersebut, konflik kepentingan dalam pengelolaan sumberdaya antar stakeholders tidak dapat dihindari. Pendekatan sentralistik masih dominan dalam perkembangan program kawasan konservasi di Indonesia, meskipun hukum otonomi lokal telah dibuat tahun 1999 yang otoritasnya pengelolaan sumberdaya perikanan diberikan kepada pemerintah lokal (Satria et al. 2006). Selanjutnya, revisi zonasi dilakukan dengan dikeluarkannya SK Dirjen PHKA No. 79/IV/Set-3/2005 dan diperbaharui kembali dengan SK Dirjen PHKA No. 28/IV-Set/2012, namun hanya melibatkan elemen masyarakat tertentu.

Purwanti et al. (2008) memaparkan bahwa adanya perbedaan kepentingan dan permasalahan yang dihadapi TNKJ telah menimbulkan konflik karena adanya perbedaan interpretasi terhadap aturan (BTNKJ dan Pemda Kabupaten Jepara dalam hal pemanfaatan ruang dan kewenangan pengelolaan TNKJ) dan antara BTNKJ dengan masyarakat Karimunjawa karena kurangnya pemahaman masyarakat terhadap tujuan pengelolaan. Selain itu, Satria et al. (2013) menyatakan bahwa adanya
TNKJ dianggap tidak pernah melakukan upaya-upaya untuk meningkatkan kesejahteraan nelayan.

Konflik kepentingan dalam pemanfaatan sumberdaya juga terjadi di beberapa taman nasional laut di Indonesia. Dalam penelitian Sembiring et al. (2010) di Taman Nasional Teluk Cenderawasih (TNTC) terdapat zona inti ("zona tabungan") yang membatasi ruang gerak nelayan tradisional. Begitupula dengan penelitian Hanan (2010) di Taman Nasional Wakatobi, masih terdapat masyarakat yang memiliki persepsi negatif terhadap taman nasional yang dianggap sebagai bentuk pengusiran masyarakat dari wilayah kelola.

Konflik ini tidak hanya terjadi di taman nasional Indonesia, namun terjadi pula di kawasan konservasi laut luar Indonesia. Menurut persepsi para nelayan, adanya kawasan konservasi telah menyebabkan penurunan dalam penangkapan ikan, meskipun nelayan menangkap ikan hanya untuk pemenuhan kebutuhan hidup. Secara umum nelayan kurang memahami mengenai aturan dan lokasi garis batas (zona). Pihak pengelola kawasan konservasi laut dianggap kurang dalam menyampaikan informasi tersebut karena komunikasi antara pihak-pihak terkait tidak berjalan dengan baik (Castro dan Cruz 2009, Trung Ho et al. 2012, Hamilton 2012, Jentoft et al. 2012, serta Bennett dan Dearden 2013). Beberapa hasil penelitian yang telah dikemukakan, menunjukkan bahwa baik di kawasan konservasi laut di Indonesia maupun luar Indonesia, masih belum menjelaskan mengenai adanya perbedaan persepsi dapat memicu timbulnya konflik. Dengan demikian, penelitian tentang hal tersebut menjadi penting untuk dilakukan. Penelitian ini bertujuan untuk mendeskripsikan dan menganalisis hubungan karakteristik 
sosial dan tingkat kepercayaan dengan persepsi pengelolaan sumberdaya perikanan di kawasan TNKJ.

\section{TINJAUAN PUSTAKA}

Pengelolaan sumberdaya perikanan tidak terlepas dari adanya perbedaan kepentingan di antara para stakeholder terkait. Konflik "ada bilamana terjadi saat tidak sesuai dengan aktivitas" (Deutsh 1973 dalam Gudykunst dan Kim 1997). Konflik tidak dapat dihindari dalam setiap hubungan yang berlangsung. Konflik dapat muncul dari persepsi yang bertentangan. Gifford (1987) menyatakan bahwa persepsi manusia terhadap lingkungan dipengaruhi oleh karakteristik personal, karakteristik budaya, dan karakteristik fisik dari lingkungan itu sendiri. Hal lain yang mempengaruhi persepsi adalah kepercayaan. Persepsi terhadap aspek pengelolaan sumberdaya perikanan (Ruddle 1999 dalam Satria 2009) difokuskan pada batas wilayah berupa zonasi, aturan, pemegang otoritas, dan sanksi.

\section{METODE PENELITIAN}

Penelitian dirancang dengan menggunakan kombinasi pendekatan kuantitatif dan kualitatif dengan menggunakan metode survai yang bersifat deskriptif korelasional (Singarimbun dan Effendi 2008). Penelitian dilaksanakan di kawasan Taman Nasional Karimunjawa dengan pemilihan Desa Karimunjawa, Kecamatan Karimunjawa, Kabupaten Jepara. Penelitian dilaksanakan pada bulan Desember 2014 sampai Januari 2015. Jumlah sampel dalam penelitian ini adalah 46 orang nelayan yang dilakukan dengan pengambilan sampel acak sederhana. Analisis statistik menggunakan korelasi Rank Spearman dan Chi-Square. Pengolahan data menggunakan Microsoft Excel 2007 dan SPSS 20.0

\section{HASIL DAN PEMBAHASAN} Karakteristik Nelayan Karimunjawa Umur responden nelayan termasuk kategori sedang, yaitu antara 34-47 tahun. Pada kisaran umur ini, responden termasuk dalam usia produktif karena secara fisik memungkinkan nelayan untuk bekerja secara optimal. Selain itu, nelayan relatif lebih mudah menerima informasi, baik dari masyarakat setempat maupun nelayan pendatang dari luar desa, meskipun masih bersifat lokalit. Sebagian besar tingkat pendidikan formal responden termasuk kategori rendah. Hampir seluruh nelayan di Karimunjawa memulai pekerjaan menjadi nelayan sejak kecil pada saat di sekolah dasar. Kondisi ini disebabkan faktor ekonomi yang menuntut anakanak bekerja membantu orang tua.

Pengalaman sebagian besar nelayan (50\%) dalam mengelola sumberdaya perikanan termasuk kategori rendah, yaitu 8-22 tahun. Hal ini disebabkan nelayan memiliki pekerjaan sampingan sebagai pemandu wisata (tour guide), akibat perkembangan pariwisata yang terus meningkat di Karimunjawa. Terdapat nelayan responden $(10,87 \%)$ mencoba pekerjaan lain, seperti bekerja di mebel, tukang bangunan, dan jasa angkutan barang sebagai upaya diversifikasi pendapatan. Mayoritas responden berasal dari Karimunjawa yang mempunyai latar belakang orang tua berasal dari suku Jawa, Madura, Bugis, dan Buton. Sebagian besar penduduk asli Karimunjawa sudah bermigrasi ke daerah lain. 


\section{Kepercayaan}

Berdasarkan Tabel 1, lebih dari $50 \%$ responden memiliki tingkat kepercayaan yang masih rendah terhadap BTNKJ. Hal ini karena BTNKJ masih belum mampu menjelaskan aturan yang berlaku kepada nelayan, sehingga kesadaran nelayan agar patuh terhadap aturan masih rendah. Komunikasi yang terjalin di antara BTNKJ dan nelayan juga dapat dikatakan tidak efektif karena pihak BTNKJ hampir tidak pernah berbaur dengan nelayan. Nelayan beranggapan bahwa kepercayaan masyarakat tidak akan terbentuk selama belum terjalin komunikasi yang baik antara pihak BTNKJ dengan nelayan.

Tabel 1 Persentase responden nelayan menurut tingkat kepercayaan terhadap BTNKJ di Desa Karimunjawa, 2015

\begin{tabular}{lc}
\hline $\begin{array}{c}\text { Tingkat } \\
\text { kepercayaan } \\
\text { terhadap BTNKJ }\end{array}$ & Persentase $(\%)$ \\
\hline Rendah & \\
Sedang & 54.35 \\
Tinggi & 28.26 \\
\hline Total & 17.39 \\
\hline
\end{tabular}

Menurut Satria et al. (2013), kepercayaan nelayan terhadap BTNKJ berada di urutan ketiga setelah juragan dan LSM Wildlife Conservation Society (WCS) dalam penyampaian upaya konservasi. Bennett dan Dearden (2013) mengungkapkan bahwa nelayan di sekitar kawasan konservasi Thailand sering tidak percaya terhadap Departemen Taman Nasional, Margasatwa, dan Konservasi Tanaman (DNP) dan beranggapan lebih baik masyarakat yang melindungi kawasan. Ongare et al. (2013) menyatakan bahwa secara umum penduduk tidak mempercayai orang luar dan adanya batasan bahasa dalam penerapan komunikasi. Ditinjau dari perspektif kepercayaan, orang yang dituakan dan pertemuan komunitas menjadi saluran komunikasi yang paling efisien karena adanya akses, keakraban, dan kurangnya hambatan bahasa. Berbeda pada hasil penelitian Jentoft et al. (2012), nelayan di Lira merasa percaya dan diberdayakan karena terdapat hubungan personal dengan pemerintahan dan ilmuwan terkait dengan kawasan konservasi laut.

\section{Media Komunikasi}

Komunikasi terbentuk dalam penyampaian pesan (informasi) dari pihak BTNKJ sebagai pengirim pesan (sender) kepada masyarakat terutama nelayan (receiver). Dalam hal ini, penggunaan media komunikasi sebagai salah satu sarana untuk penyampaian pesan sudah terealisasi di kawasan TNKJ. Pembuatan media dilakukan dengan cara pembuatan poster dan leaflet keanekaragaman hayati pada tahun 2002 dan 2003. Lalu, pada tahun 2004, adanya pembuatan leaflet pengelolaan TNKJ (dalam bahasa Indonesia dan Inggris), serta pembuatan leaflet wisata alam Karimunjawa (BTNKJ 2008). Selain itu, adanya Program Kampanye RARE Pride yang memfokuskan pada Kampanye Zona Inti yang merupakan salah satu program kerjasama antara BTNKJ, LSM WCS, dan LSM RARE. Program ini berlangsung pada tahun 2011-2012 dan merupakan salah satu upaya untuk memberikan informasi kepada nelayan tentang zona inti.

Pada hasil penelitian Widyatmoko et al. (2012), media komunikasi dalam Program Kampanye Zona Inti yang mampu menyampaikan efek komunikasi dua arah berupa SMS (Short Message Service) sebesar 35.5\% dengan interval penerimaan SMS sebanyak 21-30 kali. Kegiatan ini 
dinamakan SMS blast. Selain SMS blast, terdapat kegiatan lainnya (BTNKJ 2012), seperti pemasangan spanduk, poster, penempelan stiker tanda batas zona inti, iklan layanan masyarakat melalui RRI Semarang, dan sebagainya. Namun demikian, sebagian besar masyarakat nelayan masih belum mengerti maksud dari penggunaan media tersebut dan hanya selintas melihat dan mendengar karena kurangnya komunikasi terhadap informasi yang disampaikan. Kampanye RARE Pride masih berlanjut di tahun 2013, namun tidak lagi difokuskan pada Kampanye Zona Inti. Kampanye yang dilakukan pada tahun 2013, yaitu mengenai pengambilan ikan kerapu sesuai dengan ukurannya serta zona pemanfaatan wisata. Hal ini membuat masyarakat berpersepsi negatif kembali terhadap BTNKJ karena penyampaian pesan hanya berdasarkan program.

Papan pengumuman juga digunakan sebagai media komunikasi. Papan-papan ini biasanya ditaruh di pinggir jalan agar orang yang melintas dapat melihatnya. Salah satu contoh papan pengumuman adalah larangan menangkap dan mengambil ikan dengan menggunakan bom, potasium, dan kompresor. Penggunaan bom dan potasium dapat merusak terumbu karang dan mematikan ikan-ikan kecil, serta penggunaan kompresor dapat merusak kesehatan yang dapat mengakibatkan kelumpuhan bahkan kematian. Namun demikian, masih terdapat nelayan yang tidak peduli dengan penjelasan pada papan tersebut. Penggunaan kompresor masih banyak digunakan oleh nelayan tembak di Dusun Lego, Desa Karimunjawa. Para nelayan ini beranggapan bahwa dengan menggunakan alat bantu kompresor, pendapatan akan meningkat. Pihak BTNKJ sudah melakukan upaya kerja sama dengan LSM WCS untuk melakukan sosialisasi mengenai kompresor, namun para nelayan tembak ini tetap melakukan penangkapan ikan dengan menggunakan alat bantu kompresor.

\section{Persepsi \\ Persepsi Nelayan terhadap Zonasi}

Berdasarkan Tabel 2, dapat diketahui bahwa persepsi responden terhadap zonasi adalah merugikan bagi nelayan. Hal ini disebabkan oleh zona inti lebih luas daripada zona yang lain, zona inti dekat dari kawasan penangkapan ikan, dan di sekitar kawasan zona inti tidak terdapat tanda batas yang jelas (pelampung atau buoy yang berwarna merah). Sebagian besar nelayan mengetahui maksud dari pembuatan zona inti dan lokasi zona inti dengan adanya informasi yang didapatkan (dari teman sesama nelayan, kampanye zona inti, dan sebagainya) dan nelayan cenderung mematuhinya karena takut dengan sanksi. Namun demikian, masih terdapat nelayan yang memasuki kawasan zona inti karena dianggap tidak ada yang mengetahuinya. Nelayan yang berani menangkap ikan di sekitar kawasan zona inti dilakukan pada malam hari. Itupun hanya dilakukan oleh sebagian kecil nelayan, mengingat sanksinya relatif berat.

Tabel 2 Persentase persepsi responden nelayan terhadap zonasi di kawasan TNKJ, Desa Karimunjawa, 2015

\begin{tabular}{|c|c|}
\hline $\begin{array}{c}\text { Persepsi responden } \\
\text { nelayan terhadap zonasi }\end{array}$ & $\begin{array}{l}\text { Persentase } \\
(\%)\end{array}$ \\
\hline Merugikan & 52.17 \\
\hline Cukup merugikan & 36.96 \\
\hline Menguntungkan & 10.87 \\
\hline Total & 100.00 \\
\hline
\end{tabular}

Hal ini didukung oleh hasil penelitian Sembiring (2010) yang 
mengungkapkan bahwa penetapan zonasi Taman Nasional Teluk Cenderawasih telah membatasi ruang gerak nelayan tradisional khususnya di zona inti yang merupakan "zona tabungan". Hal ini menimbulkan konflik karena dalam zona inti terdapat hasil laut yang melimpah. Hasil penelitian Trung Ho et al. (2012), beberapa responden di Nha Trang dan Con dao, Vietnam mempersepsikan perkembangan kawasan konservasi memiliki dampak negatif terhadap kehidupan terutama bagi keluarga yang menangkap ikan di kawasan yang saat ini dijadikan zona inti dalam kawasan konservasi. McClanahan et al. (2014) mengungkapkan bahwa persepsi paling negatif terhadap batasan ditemukan di desa-desa dekat kawasan penutupan penangkapan ikan karena terdapat ketergantungan terhadap sumberdaya laut dan angka yang tinggi dalam pekerjaan per rumah tangga, tetapi tidak menggantungkan hidupnya pada pertanian, peternakan dan pariwisata. Hasil penelitian Castro dan Cruz (2009) tidak sepakat karena sebagian besar nelayan komersial di Alentejo pada tahun 2008, menyetujui adanya keberlanjutan larangan mengambil cadangan laut di beberapa kawasan konservasi.

Persepsi BTNKJ terhadap zonasi TNKJ adalah menguntungkan bagi nelayan karena ikan yang masuk dapat berkembangbiak di dalam zona inti dan dapat ditangkap kembali oleh nelayan jika ikan-ikan tersebut sudah besar dan keluar dari zona inti. Berbagai macam jenis ikan dapat dilestarikan dengan adanya zona inti.

\section{Persepsi Nelayan terhadap Aturan}

Berdasarkan Tabel 3, dapat disimpulkan bahwa persepsi responden terhadap aturan BTNKJ termasuk banyak dan ketat. Sebagaimana diketahui bahwa aturan yang telah dibuat sudah baik karena melalui proses dalam pembuatannya. Namun demikian, aturan yang banyak dan harus dipatuhi serta ketatnya aturan tersebut mengakibatkan sebagian besar nelayan merasa terkekang untuk melaut di wilayahnya sendiri. Informasi mengenai aturan didapatkan dari teman sesama nelayan, LSM WCS, BTNKJ, dan DKP. Aturan yang terdapat di kawasan TNKJ meliputi larangan memasuki zona inti, larangan mengambil jenis ikan yang tidak diizinkan untuk ditangkap, larangan penggunaan alat tangkap yang tidak ramah lingkungan, dan larangan menangkap ikan pada musim ikan berkembangbiak.

Hasil penelitian Jentoft et al. (2012), terlihat sama dengan kondisi di BTNKJ, nelayan di L'Estartit-Medes Islands dan La Restinga mempersepsikan bahwa aturan dari kawasan konservasi dianggap tidak adil bagi nelayan, namun berbeda dengan nelayan di Lira yang mempersepsikan bahwa aturan sudah memadai untuk mencapai tujuan kawasan konservasi. Bennett dan Dearden (2013) menunjukkan bahwa terdapat dampak minimal pada nelayan karena peraturan DNP mengizinkan nelayan skala kecil memancing di kawasan konservasi sepanjang nelayan mengikuti aturan Departemen Perikanan atau peraturan DNP tidak secara teknis mengizinkan penangkapan ikan di kawasan konservasi, tetapi pengelola tidak memaksakan peraturan. Begitupula dengan hasil penelitian McClanahan et al.(2014), aturan mengenai penutupan kawasan, tidak menguntungkan dan mengurangi daerah tangkapan ikan serta terdapat pembatasan alat tangkap, maka tidak dapat menangkap jenis ikan tertentu, dan tidak menguntungkan jika jenis ikan dipilih. 
Tabel 3 Persentase persepsi responden nelayan terhadap aturan BTNKJ, Desa Karimunjawa, 2015

\begin{tabular}{lc}
\hline \multicolumn{1}{c}{\begin{tabular}{c} 
Persepsi responden \\
nelayan terhadap aturan \\
\multicolumn{1}{c}{ BTNKJ }
\end{tabular}} & $\begin{array}{c}\text { Persentase } \\
(\%)\end{array}$ \\
\hline Banyak dan ketat & 54.35 \\
Banyak namun tidak ketat & 41.30 \\
Tidak banyak dan tidak & 4.35 \\
ketat & \\
\hline Total & 100.00 \\
\hline
\end{tabular}

Persepsi BTNKJ terhadap aturan adalah aturan di kawasan TNKJ dibuat untuk menjaga keseimbangan ekosistem dan demi kesejahteraan nelayan. Nelayan juga diikutsertakan dalam pembuatan rezonasi pada tahun 2011, sehingga aturan yang dibuat tidak bersifat top-down. Pihak BTNKJ menganggap bahwa pola pikir dan tingkat kesadaran nelayan terhadap sumberdaya alam masih rendah. Pelanggaran aturan di kawasan TNKJ masih terjadi hingga saat ini. Para nelayan dianggap belum mampu memikirkan keberlanjutan dan kelestarian sumberdaya hayati perairan.

Kebijakan antara BTNKJ dan Dinas Kelautan dan Perikanan (DKP) di dalam kawasan TNKJ mengalami tumpang tindih, sehingga mengakibatkan nelayan kurang memahami aturan yang harus dipatuhi. Aturan yang berlaku menurut BTNKJ di bawah Kementerian Kehutanan (Kemenhut) mengacu pada UU No 5 Tahun 1990 serta PP RI No. 68 Tahun 1998 dan permasalahan zonasi mengacu pada SK Dirjen PHKA No. 28/IVSet/2012. Aturan menurut DKP di bawah Kementerian Kelautan dan Perikanan (KKP) adalah UU No. 45 tahun 2009 dan UU No. 1 Tahun 2014. Hal ini didukung oleh Satria et al. (2006) bahwa terdapat perbedaan persepsi antara Kemenhut dan KKP dalam memperhatikan konservasi dan melestarikan sumberdaya alam. KKP mengembangkan kebijakan konservasi dalam dasar perlindungan ekosistem yang memisahkan kawasan dan jenis satwa ke dalam kategori yang dilindungi dan tidak dilindungi. Jenis ikan juga diklasifikasikan ke dalam dilindungi dan tidak dilindungi dimana kawasan penangkapan ikan, musim dan ukuran ikan tidak dipertimbangkan dalam pengelolaan. Menurut KKP, konservasi laut merupakan hal yang mudah jika diperlakukan dengan caracara tertentu karena KKP percaya bahwa pengelolaan daratan berbeda dengan pengelolaan laut.

\section{Persepsi Nelayan terhadap Pemegang Otoritas}

Pihak BTNKJ adalah pemegang otoritas yang melaksanakan tugas dalam mengelola kawasan TNKJ, baik di darat maupun laut. Tabel 4 menunjukkan bahwa persepsi responden terhadap pihak BTNKJ, yaitu BTNKJ tidak peduli terhadap masyarakat. Persepsi responden terhadap BTNKJ adalah BTNKJ memiliki kekuasaan dan wewenang yang kuat, tetapi belum mampu melibatkan masyarakat untuk bekerja sama dalam mengelola kawasan TNKJ karena hanya mengikutsertakan pihak-pihak tertentu saja, seperti pembentukan MMP. Pihak BTNKJ dianggap belum mampu memberdayakan masyarakat di sekitar kawasan TNKJ. Komunikasi yang dilakukan oleh BTNKJ masih terbatas pada program yang dijalankan, seperti ditunjukkan pada kampanye zona inti. Pihak BTNKJ yang bekerjasama dengan LSM WCS dan RARE menyampaikan pesan berupa informasi mengenai zona inti, namun masih kurang melibatkan partisipasi nelayan.

Hasil penelitian Bennett dan Dearden (2013) mendukung temuan penelitian yang ditunjukkan oleh 
pemegang otoritas di kawasan konservasi Thailand adalah Department of National Parks, Wildlife and Plant Conservation (DNP). Persepsi responden terhadap DNP adalah pengawasan DNP hanya di pulau-pulau saja, namun tidak terdapat pengontrolan di laut. Salah satu pihak LSM yang terdapat di kawasan tersebut mengatakan bahwa DNP salah dalam menggunakan otoritas. Pihak DNP tidak peduli dengan sumberdaya dan hanya bertindak seolah-olah memilikinya. Penelitian Trung Ho et al. (2012) juga menyatakan bahwa persepsi positif terhadap pemegang otoritas tergantung pada kebutuhan hidup yang dapat dipenuhi oleh pemegang otoritas. Komunitas lokal akan meningkatkan persepsi dan kesadaran mengenai isu lingkungan dan degradasi sumberdaya setelah mendapatkan pendidikan mengenai lingkungan dari pemegang otoritas kawasan konservasi.

\begin{tabular}{|c|c|c|}
\hline Tabel 4 & $\begin{array}{l}\text { Persentase } \\
\text { responden nel } \\
\text { pemegang ot } \\
\text { Desa Karimunj }\end{array}$ & $\begin{array}{lr} & \text { perseps } \\
\text { an } & \text { terhadap } \\
\text { itas } & \text { TNKJ } \\
\text { va, } 2015\end{array}$ \\
\hline $\begin{array}{r}\text { Pers } \\
\text { nel } \\
\text { pemega }\end{array}$ & $\begin{array}{l}\text { psi responden } \\
\text { yan terhadap } \\
\text { ng otoritas TNKJ }\end{array}$ & $\begin{array}{l}\text { Persentase } \\
\quad(\%)\end{array}$ \\
\hline $\begin{array}{l}\text { Tidak p } \\
\text { masyara }\end{array}$ & $\begin{array}{l}\text { duli terhadap } \\
\text { kat }\end{array}$ & 56.52 \\
\hline $\begin{array}{l}\text { Kurang } \\
\text { masyara }\end{array}$ & $\begin{array}{l}\text { peduli terhadap } \\
\text { kat }\end{array}$ & 39.13 \\
\hline $\begin{array}{l}\text { Peduli t } \\
\text { masyara }\end{array}$ & $\begin{array}{l}\text { rhadap } \\
\text { kat }\end{array}$ & 4.35 \\
\hline Total & & 100.00 \\
\hline
\end{tabular}

Pihak BTNKJ sebagai pemegang otoritas mempersepsikan dirinya sebagai pengelola kawasan TNKJ yang menjalankan tugas untuk melindungi kawasan konservasi. Tugas yang dilakukan oleh pihak BTNKJ memerlukan dukungan dari masyarakat sekitar kawasan karena masyarakat turut mengakses sumberdaya yang ada di kawasan TNKJ, baik darat maupun laut.
Akan tetapi, pihak BTNKJ selalu dianggap musuh oleh masyarakat yang tidak menyukai keberadaan BTNKJ. Sebagaimana diketahui, TNKJ telah terbentuk sejak tahun 1986 dan hingga saat ini, permasalahan yang terjadi antara BTNKJ dan nelayan terus berlanjut terutama hal yang berkaitan dengan pemenuhan hidup masyarakat sekitar kawasan TNKJ. Selain itu, LSM WCS turut membantu dalam mendukung pengelolaan kawasan TNKJ yang lebih efektif, meskipun LSM WCS berpihak kepada BTNKJ bukan kepada nelayan karena adanya kesepakatan kerjasama kemitraan sejak tahun 1997.

\section{Persepsi Nelayan terhadap Sanksi}

Sanksi diberikan pada pelanggar aturan. Tabel 5 menjelaskan bahwa persepsi responden terhadap sanksi termasuk kategori sedang sebesar 52.17 $\%$. Informasi mengenai sanksi didapatkan dari teman sesama nelayan, LSM WCS, BTNKJ, dan DKP bahkan ada yang melihat secara langsung pemberian sanksi. Persepsi responden mengenai sanksi bahwa pemberlakuan sanksi ekonomi dan sanksi hukum sudah cukup efektif untuk dilakukan. Nelayan merasa ketakutan karena sanksinya bersifat tegas, nyata, mengikat, dan memaksa, sehingga tidak ingin melakukan pelanggaran terutama yang berhubungan dengan hukuman pidana. Para nelayan Karimunjawa masih memikirkan keluarga karena jika melakukan pelanggaran, maka merasa malu dengan lingkungan sekitar.

Tabel 5 Persentase persepsi responden nelayan terhadap sanksi TNKJ, Desa Karimunjawa, 2015

\begin{tabular}{|c|c|}
\hline $\begin{array}{c}\text { Persepsi responden } \\
\text { nelayan terhadap sanksi } \\
\text { TNKJ }\end{array}$ & $\begin{array}{c}\text { Persentase } \\
(\%)\end{array}$ \\
\hline Tidak efektif & 28.26 \\
\hline Cukup efektif & 52.17 \\
\hline
\end{tabular}


Efektif

19.57

Total

100.00

Persepsi BTNKJ terhadap sanksi adalah cukup efektif karena pelanggaran yang terjadi di sekitar kawasan TNKJ semakin berkurang. Para nelayan masih merasa takut jika tidak sengaja tertangkap oleh pihak BTNKJ atau MMP. Bila satu sampai dua kali tertangkap, hanya diberi peringatan atau hukuman ekonomi (denda dan atau penyitaan barang). Jika pelanggaran sudah sampai untuk ketiga kalinya tertangkap, maka akan dikenakan vonis hingga dibawa ke Semarang (sanksi hukum). Hal ini didukung dalam penelitian Arias dan Sutton (2013) bahwa nelayan komersial di Taman Laut The Great Barrier Reef percaya tentang hukuman bagi yang melanggar aturan jika tertangkap menangkap ikan

Tabel 6 Nilai koefisien korelasi karakteristik sosial menurut persepsi aspek pengelolaan sumberdaya perikanan di kawasan TNKJ, Desa Karimunjawa, 2015

\begin{tabular}{lllcl}
\hline Peubah karakteristik sosial & Zonasi & Aturan & Pemegang otoritas & Sanksi \\
\hline Umur & $0.311^{*}$ & $0.318^{*}$ & $0.423^{* *}$ & 0.207 \\
Tingkat pendidikan formal & 0.043 & 0.087 & -0.028 & -0.152 \\
Pengalaman mengelola & $0.408^{* *}$ & $0.381^{* *}$ & $0.454^{* *}$ & $0.334^{*}$ \\
sumberdaya perikanan $^{1}$ & 0.042 & 0.112 & 0.549 & 0.043 \\
Pekerjaan sampingan $^{1)}$ & 0.604 & 0.377 & 0.106 & 0.330 \\
Asal daerah ${ }^{1)}$ &
\end{tabular}

**nyata pada taraf $\alpha=0.01 ; *$ nyata pada taraf $\alpha=0.05$
Berdasarkan hasil uji statistik dengan menggunakan korelasi Rank Spearman (Tabel 6), diketahui bahwa terdapat hubungan nyata dan positif antara umur dan persepsi menurut zonasi (0.311) serta umur dan persepsi menurut aturan (0.318). Lalu, terdapat hubungan sangat nyata dan positif antara umur dan persepsi menurut pemegang otoritas (0.423). Semakin rendah umur seseorang, maka semakin negatif persepsinya terhadap zonasi, aturan, dan pemegang otoritas. Hamilton (2012) menyatakan bahwa umur yang semakin tua pada nelayan di zona larang tangkap oleh pemegang otoritas, maka akan dilakukan penyitaan barang, peringatan, sidang pengadilan, atau bahkan dipenjara.

\section{Konflik akibat Perbedaan Persepsi}

\section{Hubungan Karakteristik Sosial Responden terhadap Persepsi dalam Pengelolaan Sumberdaya Perikanan}

Peubah pada karakteristik sosial yang digunakan untuk uji korelasi Rank Spearman adalah umur, tingkat dalam pendidikan formal, dan pengalaman pengelolaan sumberdaya perikanan, sedangkan peubah pekerjaan sampingan dan asal daerah menggunakan tabulasi silang dengan uji Chi-square. Hasil uji statistik ditunjukkan pada Tabel 6.
Kamboja menunjukkan dukungan terhadap kawasan konservasi dan bagi nelayan di Filipina, umur tidak mempengaruhi persepsi terhadap kawasan konservasi.

Pada pengalaman dalam mengelola sumberdaya alam, terdapat hubungan nyata dan positif antara pengalaman mengelola sumberdaya dan persepsi menurut sanksi (0.334). Selain itu, terdapat hubungan sangat nyata dan positif antara pengalaman mengelola sumberdaya perikanan dan persepsi menurut zonasi (0.408), pengalaman mengelola sumberdaya perikanan dan aturan (0.381), serta pengalaman 
mengelola sumberdaya perikanan dan persepsi menurut pemegang otoritas (0.454). Semakin rendah pengalaman mengelola sumberdaya alam, semakin negatif persepsi para nelayan terhadap zonasi, aturan, pemegang otoritas, dan sanksi. Para nelayan yang belum lama melaut menyatakan bahwa tidak terlalu mempedulikan zona larang tangkap karena pernyataan nelayan bahwa ikan termasuk sumberdaya yang tidak akan habis. Penelitian Leleu et al. (2012) memberikan hasil yang berbeda bahwa semakin kurang lama dalam pengalaman menangkap ikan, semakin positif persepsinya tentang zona larang tangkap. Para nelayan Karimunjawa yang belum lama melaut mengakui bahwa aturan diperlukan, namun aturan yang ada saat ini terlalu banyak dan berlebihan. Begitupula dengan persepsi nelayan terhadap BTNKJ sebagai pemegang otoritas. Pihak BTNKJ belum terlalu mempedulikan kehidupan nelayan sekitar karena tugas utamanya untuk melindungi kawasan konservasi.

Pada peubah tingkat pendidikan formal, diketahui bahwa tidak terdapat hubungan antara pekerjaan sampingan dengan persepsi terhadap zonasi, aturan, dan pemegang otoritas, dan sanksi. Begitupula pada peubah pekerjaan sampingan dan asal daerah yang diketahui bahwa tidak terdapat hubungan dengan persepsi menurut aspek pengelolaan sumberdaya perikanan di kawasan TNKJ berdasarkan hasil uji statistik dengan menggunakan korelasi Chi Square (Tabel 6).

Tabel 7 Hubungan tingkat kepercayaan terhadap BTNKJ menurut persepsi terhadap aspek pengelolaan sumberdaya perikanan di kawasan TNKJ, Desa Karimunjawa, 2015

\begin{tabular}{ccccc}
\hline Peubah & Zonasi & Aturan & Pemegang otoritas & Sanksi \\
\hline Kepercayaan & $0.465^{* * *}$ & $0.490^{* * *}$ & $0.581^{* * * *}$ & $0.673^{* * * *}$ \\
\hline$* * *$ nyata pada taraf $\alpha=0.01$ & & &
\end{tabular}

Persepsi merupakan inti dari komunikasi. Persepsi memerankan (2008), persepsi nelayan terhadap pembatasan pengelolaan dan manfaat hanya lemah berkorelasi dengan status sosial ekonomi penduduk desa, baik di dalam maupun di luar Taman Laut Pulau Mafia, Tanzania. Selanjutnya, McClanahan et al. (2014) mengungkapkan bahwa terdapat hubungan positif antara faktor sosial ekonomi (pengambilan keputusan komunitas, jumlah pekerjaan, dan lokasi daratan) terhadap persepsi keuntungan yang diterima dalam perbedaan pilihan pengelolaan.

\section{Hubungan Kepercayaan terhadap BTNKJ menurut Persepsi dalam Aspek Pengelolaan Sumberdaya Perikanan}

Peubah

kepercayaan

menggunakan uji korelasi Rank Spearman. Hasil uji tersebuut menunjukkan bahwa terdapat hubungan sangat nyata, positif, dan kuat antara peubah kepercayaan dan persepsi dalam aspek zonasi, aturan, pemegang otoritas, dan sanksi (Tabel 7). Semakin rendah kepercayaan seseorang, maka akan semakin rendah persepsinya terhadap aspek zonasi, aturan, pemegang otoritas, dan sanksi. Hal ini sesuai dengan penelitian Bennett dan Dearden (2013) bahwa terdapat hubungan kepercayaan mengenai pemenuhan kehidupan dan hasil konservasi dengan persepsi pengelolaan dan pemerintahan. 
peran yang penting dalam konflik, yaitu sebagai tujuan perselisihan (Lumsden dan Lumsden 2000 dalam Littlejohn dan Domenici 2007). Berdasarkan hasil yang telah dipaparkan, dapat diketahui bahwa terdapat konflik vertikal (perbedaan status sosial) antara nelayan Desa Karimunjawa dan BTNKJ. Dalam kasus ini masih dianggap memiliki akar yang dangkal dan muncul hanya adanya kesalahpahaman mengenai persepsi yang memunculkan konflik tertutup. Nelayan yang memiliki perbedaan persepsi dengan BTNKJ memiliki ciriciri, seperti nelayan yang tempat tinggalnya berdekatan dengan kantor BTNKJ, nelayan yang tidak diikutsertakan dalam kegiatan BTNKJ, umur yang masih muda, dan pengalaman melaut yang masih kurang.

\section{SIMPULAN DAN SARAN Simpulan}

Media komunikasi sudah dipergunakan oleh pihak BTNKJ sebagai upaya untuk memberikan informasi kepada nelayan. Akan tetapi, para nelayan membutuhkan penjelasan lebih rinci dengan adanya penggunaan media tersebut. Tingkat kepercayaan responden nelayan terhadap pihak BTNKJ masih tergolong rendah. Hal ini dikarenakan komunikasi yang terjalin di antara BTNKJ dan nelayan dapat dikatakan tidak efektif karena pihak BTNKJ hampir tidak pernah berbaur dengan nelayan. Sebagian besar responden nelayan masih memiliki persepsi negatif terhadap pemberlakuan zonasi (merugikan), aturan (banyak dan terlalu ketat), dan pemegang otoritas (tidak peduli terhadap masyarakat nelayan).

Perbedaan persepsi antara BTNKJ dan nelayan termasuk konflik vertikal (perbedaan kekuasaan) dan berdasarkan tipe konflik termasuk konflik tertutup yang bersifat tersembunyi dan perlu diangkat ke permukaan. Hasil penelitian ini menunjukkan bahwa terdapat hubungan antara karakteristik sosial dan persepsi pengelolaan sumberdaya perikanan serta tingkat kepercayaan terhadap BTNKJ menurut persepsi pengelolaan sumberdaya perikanan. Oleh karena itu, ciri-ciri nelayan yang memiliki perbedaan persepsi, sehingga mampu menimbulkan konflik dengan BTNKJ adalah nelayan yang tempat tinggalnya berdekatan dengan kantor BTNKJ, nelayan yang tidak diikutsertakan dalam kegiatan BTNKJ, umur yang masih muda, dan pengalaman melaut yang masih kurang.

\section{Saran}

Implikasi dari adanya pengelolaan sumberdaya perikanan di kawasan TNKJ berupa zonasi, aturan, pemegang otoritas, dan sanksi, maka diperlukan upaya yang mengarah pada komunikasi interaktif antara BTNKJ dan nelayan agar terjadi persamaan persepsi. Pihak BTNKJ perlu mengkader nelayan tokoh muda sebagai liaison officer (penghubung antara satu pihak nelayan dengan pihak nelayan lainnya) untuk membangun hubungan kepercayaan dan jalinan kerjasama yang baik dengan nelayan-nelayan lain. Terkait kebijakan antara BTNKJ dan DKP, diperlukan pembahasan yang rinci sebelum disosialisasikan kepada nelayan, sehingga aturan yang disampaikan dapat diterima oleh nelayan dengan bahasa yang mudah dimengerti. Nelayan juga harus mampu mengubah persepsinya terhadap BTNKJ dengan berusaha memahami pekerjaan pihak BTNKJ sebagai pemegang otoritas. Selain itu, diperlukan peran LSM WCS dalam menyampaikan informasi mengenai pengelolaan sumberdaya perikanan untuk seluruh nelayan (tidak hanya nelayan tembak yang 
menggunakan alat bantu kompresor yang diberikan informasi).

\section{DAFTAR PUSTAKA}

Arias A dan Sutton SG. 2013. Understanding recreational fishers' compliance with no-take zones in The Great Barrier Reef Marine Park. Ecology and Society. 18(4):18-26.

Bennett NJ, Dearden P. 2013. Why local people do not support conservation: Community perceptions of marine protected area livelihood impacts, governance and management in Thailand. Marpol. 44 (1): 107-116.

[BTNKJ] Balai Taman Nasional Karimunjawa. 2008. Statistik Balai Taman Nasional Karimunjawa tahun 2007. Semarang (ID): Balai Taman Nasional Karimunjawa.

[BTNKJ] Balai Taman Nasional Karimunjawa. 2012. Statistik Balai Taman Nasional Karimunjawa tahun 2011. Semarang (ID): Balai Taman Nasional Karimunjawa.

Castro JJ, Cruz T. 2009. Marine conservation in a Southwest Portuguese National Park. ICS, SI 56, Proceedings of the 10th International Coastal Symposium. 1 (1): 385-389.

[Dit. KKJI] Direktorat Konservasi Kawasan dan Jenis Ikan. 2013. Informasi kawasan konservasi perairan Indonesia. Jakarta (ID): Direktorat Jenderal Kelautan, Pesisir, dan Pulau-pulau Kecil, Kementerian Kelautan dan Perikanan.

Gudykunst WB, Kim YY. 1997. Communicating with strangers: An approach to intercultural communication, 3rd ed. New York
(US): McGraw-Hill Companies, Inc.

Hamilton M. 2012. Perceptions of fishermen towards marine protected areas in Cambodia and the Philippines. Bioscience Horizons. 5 (1): 1-24.

Hanan LOMS. 2010. Kajian strategi pengelolaan sumberdaya laut oleh masyarakat adat dalam kawasan Taman Nasional Wakatobi [tesis]. Bogor (ID): Institut Pertanian Bogor.

Jentoft S, Pascual-Fernandez JJ, Modino RDC, Gonzalles-Ramallal M, Chuenpagdee R. 2012. What stakeholders think about marine protected areas: Case studies from Spain. Human Ecology. 40 (2): 185-197.

Leleu K, Alban F, Pelletier D, Charbonnel E, Letourneur Y, Boudouresque CF. 2012. Fishers' perceptions as indicators of the performance of marine protected areas (MPAs). Marpol. 36 (2): 414422.

Littlejohn SW, Domenici K. 2007. Communication, conflict, and the management of differences. Illinois (US): Waveland Press, Inc.

McClanahan TR, Cinner J, Kamukuru AT, Abunge C, Ndagala J. 2008. Management preferences, perceived benefits and conflicts among resource users and managers in the Mafia Island Marine Park, Tanzania. Environmental Conservation. 35 (4): 340-350.

McClanahan TR, Cinner JE, Abunge C, Rabearisoa A, Mahatante P, Ramahatratra F, Andrianarivelo N. Ecology and Society. 2014. Perceived benefits of fisheries management restrictions in Madagascar. Ecology and Society. 19(1): 5-15. 
Ongare D, Macharia A, Mwakaje A, Muchane M, Warui C, Mugoya C, Masiga C, Nikundiwe A, Muiti A, Wakibara J. 2013. Environmental communication: A review of information sources and communication channels for enhanced community based natural resource management in the Greater Mara Region of Kenya. JSD. 7 (1): 65-74.

Purwanti F, Alikodra HS, Basuni S, Soedharma D. 2008. Pengembangan co-management Taman Nasional Karimunjawa. IJMS. 13 (3): 159-166.

Satria A, Sano M, Shima H. 2006. Politics of marine conservation area in Indonesia: from a centralised to a decentralised system. IJESD. 5 (3): 240-261.

Satria A. 2009. Pesisir dan laut untuk rakyat. Bogor (ID): IPB Press.

Satria A, Purnomo AM, Aziziy A. 2013. Pengelolaan kawasan konservasi laut secara kolaboratif: Upaya menimbang peran institusi patron klien. Di dalam: Prastowo, Sulistiono, Agik S, Bambang HS, editor. Prosiding Seminar HasilHasil Penelitian Institut Pertanian Bogor 2012, Buku 3 Bidang Sosial, Ekonomi, dan Budaya; 2012 Des 10-11; Bogor, Indonesia. Bogor (ID): LPPM IPB. hlm 625-643.

Sembiring E, Basuni S, Soekmadi R. 2010. Resolusi konflik pengelolaan Taman Nasional Teluk Cenderawasih di Kabupaten Teluk Wondama. JMHT. 16 (2): 84-91.

Singarimbun M, Effendi S. 2008.

Metode penelitian survai. Jakarta (ID): LP3S.

Trung Ho TV, Cottrell A, Valentine P, Woodley S. 2012. Perceived barriers to effective multilevel governance of human-natural systems: An analysis of Marine
Protected Areas in Vietnam. JPE. 19 (1): 17-35.

Widyatmoko BM, Purwanti F, Suryanto A. 2012. Kepedulian masyarakat dan efektivitas kampanye zona inti di Taman Nasional Karimunjawa. MARJ. 1 (1): 1-6. 
ISSN 1693-3699 (Cetak)

Jurnal Komunikasi Pembangunan

ISSN 2442-4102

Juli 2015. Vol.13, No.2

\section{Biodata Penulis}

Nama : Titania Aulia

Alamat $\quad$ : Taman Cimanggu J1. Soka VI/10 Bogor 16163

Alamat e-mail $\quad$ : titania.aulia@gmail.com

Pendidikan terakhir : S1 Departemen Sains Komunikasi dan Pengembangan Masyarakat, FEMA-IPB

Asal tulisan $\quad$ : bagian dari tesis yang Disampaikan pada Seminar Sekolah Pascasarjana IPB 